\title{
The Impacts of a Long Residue Addition to the Briquette Quality of Ketapang Fruit and Siwalan Fruit Skin Charcoals Using Amylum as Additive and a Manual Briquette Machine
}

\author{
Suparno $^{1}$ W.R. Hatiningrum ${ }^{2, *}$ A. Huzein ${ }^{3}$, R.D. Syahputra ${ }^{3}$ A.D Rahangmetang ${ }^{3}$ \\ HH Naim ${ }^{3}$
}

\author{
${ }^{1}$ Assistant Profesor at Politeknik Energi dan Mineral AKAMIGAS, 58315, Indonesia \\ ${ }^{2}$ Associate Profesor at Politeknik Energi dan Mineral AKAMIGAS, 58315, Indonesia \\ ${ }^{3}$ Students at Politeknik Energi dan Mineral AKAMIGAS,58315, Indonesia \\ *Corresponding author. Email: woro.hatiningrum@gmail.com
}

\begin{abstract}
A Long residue is a bottom product of an atmospheric distillation unit of crude oil. Generally this product is further processed in a refinery secondary unit to produce more yield. In case there is no refinery secondary process this bottom product is mixed with chemicals to produce marine fuel oil. This paper aims to describe the impacts of a long residue addition to the briquette quality of Ketapang or Terminalia catappa fruit and siwalan or Borassus flabellifer L fruit skin charcoals using amylum as an additive and a manual briquette machine. Each briquette composition consisted of $10 \%$, $20 \%$ and $30 \%$ weight of long residue respectively and, $5 \%$ weight of amylum. A manual briquette machine was used to mold the briquette. The Briquette results, then, were analyzed based on their proximate parameters and porosity. The analysis shows that the higher the long residue addition the better the briquette proximate analysis result. Some parameters such as porosity, moisture content, and calorific value fulfill the Briquette Indonesian standard nevertheless parameters such as FC, ash and volatile matter contents need to be improved. These three last parameters relate to the raw materials chosen and the performance of a charcoal furnace used. The compressive strength of the briquettes also does not fulfill the requirement as a manual molding machine was used for briquette process.
\end{abstract}

Keywords: Long Residue, Ketapang, Siwalan, Briquette, Proximate Analysis.

\section{INTRODUCTION}

A Long residue is a bottom product of an atmospheric distillation unit of crude oil. Generally this product is further processed in a refinery secondary unit to produce more yield. In case there is no refinery secondary process facility this bottom product is mixed with chemicals to produce marine fuel oil (practised in one of the refineries in Indonesia) or it was used for direct fuel in small scale industries (no longer practised). On the other hand, biomass currently is used as an energy source to substitute the use of fossil energy even though its energy content is lower than the fossil fuel. One way to increase its energy content is by converting it to a charcoal then it is molded to a briquette through several steps such as charcoal grinding up to a certain size, mixing with a certain type and amount of glue and molding using a pressurised or manual molded equipment [1]- [6]. Some raw materials used during previous research consist of coconut shell, banana skin fruit, solid waste of sugar cane industry, wood waste, corn cob. Ketapang or Terminalia catappa fruit and Siwalan or Borassus flabellifer $L$ fruit skin have been used as briquette raw materials by Sulistyorini [7] and Yuniarti [8]. A temperature used during carbonization process to produce charcoal can be a torrefaction process at $250^{\circ} \mathrm{C}-300^{\circ} \mathrm{C}[9]$ or full carbonization at $400{ }^{\circ} \mathrm{C}[10]$. The torrefaction process is ussually used to produce half-cooked charcoal for pellet production. Before the charcoal is molded to produce the briquette it should be ground to a 40 - 60 mesh in size [11] and mixed with glue. Several types of the glue used for briquette production are amylum, liquid waste of 
sugar cane industry, and dammar gum [3],[12]-[5]. To increase the briquette easiness to burn it could be added with $\mathrm{KMnO}_{4}$ [11]. When a pressurised mold equipment is used it should produce $12 \mathrm{~kg} / \mathrm{cm}^{2}$ compressive strength within the briquette (P3HH Indonesian standard [15].

Based on the previous research using biomass to produce a biomass charcoal briquette, coconut shell charcoal gives the best quality of the briquette and fulfill national and international standards [1]. Nevertheless this raw material is very hard to be found in The Indonesian market. Meanwhile, the other biomass materials give a lower quality of briquette.

The quality of the briquette follows the Indonesian National Standard (SNI) number 6235-2000 and specifies the quality as follows: a calorific value $(\mathrm{CV})>$ 5000 calorie/gram; moisture content (MC) < $8 \%$; volatile matter $(\mathrm{VM})<15 \%$; ash content $<8 \%$. All percentage is in \% weight of air dry basis (adb). The fixed carbon (FC) content is specified by $\mathrm{P} 3 \mathrm{HH}$ (Pusat Penelitian dan Pengembangan Hasil Hutan) standard instead of the SNI and it says $60 \%$. The briquette porosity and compressive strength are $>0.7 \mathrm{gram} / \mathrm{cc}$ and $>12 \mathrm{~kg} / \mathrm{cm}^{2}$ respectively $(\mathrm{P} 3 \mathrm{HH})$. The International standard such as Japan, English and USA standards put some strengten requirements for its briquette calorific value, porosity and compressive strength [16][17].

This research aims to analyze an impact of a long residue addition to the briquette quality of Ketapang fruit and Siwalan fruit skin charcoals using amylum as an additive and a manual briquette machine. The first reason why Ketapang and Siwalan fruit skin used as raw materials is because they are easily found as waste spilled during a dry season in Central Java, Indonesia. The second reason is that there is still an opportunity to improve their briquette proximate parameters using long residue. The carbonization process to produce charcoal uses the HRV carbonization tank operated at $400{ }^{\circ} \mathrm{C}$ for one hour carbonization and 3 hours cooling[18]. Amylum is used as glue as it is easier to be found in the market. The manual mold equipment is used for briquette production as it is a simpler technology which it may be easier to be adopted by villagers where this biomass exists. This equipment may not give a proper briquette performance in terms of its compressive strength. Even so, as the biomass charcoal briquette may be used as a local energy subtitution this low compressive stength parameter should not give a problem for the user. The long residue addition for briquette production varies from $10 \%, 20 \%$ up to $30 \%$ weight respectively in $5 \%$ of amylum for each. The long residue was taken from the traditional oil miners in Central Java. Before usage, the long residue was analyzed in terms of its proximate parameters and its metal contents based on a Toxicity Characteristic Leaching Procedure (TCLP) method to see whether there are metal hazards. The briquette results are then analyzed for their proximate parameters and compared the analyzed result to the Indonesian national standard requirement.

\section{METHOD}

The steps of the research are as follows shows as Figure 1.

a. Raw materials preparation of Ketapang fruit and Siwalan fruit skin

b. Raw material drying under the sun light for $3-5$ days depending on the light intention

c. Carbonization using the HRV carbonization tank, in the full capacity of $4 \mathrm{~kg}$ dry materials at $400 \mathrm{o} \mathrm{C}$ temperature of 1 hour carbonization period and 3 hours cooling period respectively.

d. Charcoal grinding and filtering up to 60 mesh in size.

e. Weighing and mixing with long residue and liquid amylum. The water content in the mixture is maintained in the $50 \%$ of weight to satisfy the molding process

f. Molding the briquette using the manual mold equipment with the briquette diamer of $5.5 \mathrm{~cm}$ and 1.5 $\mathrm{cm}$ in the thickness

g. Briquette drying for 24 hours in an ambient temperature to let drying process slowly

h. Briquette drying for $2 \times 8$ hours under the sun light

i. Conducting laboratory tests to analyze physical and proximate parameters of the briquette based on the ASTM method and comparing the result to the SNI and $\mathrm{P} 3 \mathrm{HH}$ standards.

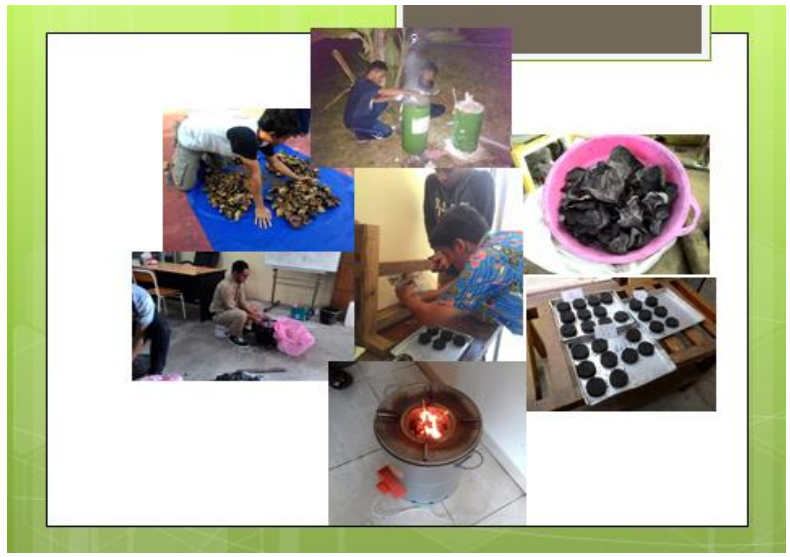

Figure 1 The steps of the research

\section{RESULT AND DISCUSSION}

\subsection{The Proximate Analysis of the Raw Materials Used}

Table 1 shows the proximate analysis of all materials used during the research. It looks that the long residue used as a briquette additive has the highest calorific value and fixed carbon content. It also has the lowest of moisture, ash and, volatile matter contents. Thus using the long residue as a briquette additive is expected to improve the physical and proximate parameters of 
briquette such as porosity, moisture, VM, ash, FC contents and, calorific value. The result of the TCLP analysis of the long residue shows that there is no metal toxic in the long residue (the analysis result is excluded from this paper). The quality of the charcoals used for Table 1. The proximate analysis of the ketapang fruit and siwalan skin fruit charcoals

\begin{tabular}{llllllll} 
No & Code & Charcoal of & CV (cal/gr) & MC $(\%)$ & Ash $(\%)$ & VM $(\%)$ & FC $(\%)$ \\
\hline 1 & P10 & Ketapang fruit & 6014 & 5,54 & 9,0 & 23,84 & 61,62 \\
2 & P12 & Ketapang fruit & 6124 & 5,96 & 10,0 & 23,60 & 60,44 \\
3 & P14 & Siwalan fruit skin & 5240 & 5,75 & 18,22 & 25,3 & 50,74 \\
4 & E & Long residue & 8518 & 0,69 & 4,41 & 19,62 & 75,28 \\
\multicolumn{2}{l}{ Note: } & All analysis results are in air dry basis & & & & \\
\hline
\end{tabular}

\subsection{The Impact of the Percentage of the Long Residue Addition to the Briquette Porosity of the Ketapang Fruit and Siwalan Fruit Skin Charcoals}

Figures 2 and 3 show the relationship between an increase of the $\%$ of long residue addition to the porosity of briquette. These two figures show that the more the \% briquette raw materials is quite similar, but the Ketapang fruit charcoal has a better proximate parameters compared to the Siwalan fruit skin charcoal specially its FC, ash contents and, its calorific value. of the long residue addition the higher the porosity of the briquette. The $10 \%, 20 \%$ and $30 \%$ of the long residue addition respectively into the Ketapang fruit charcoal briquette provides porosity more than $0,7 \mathrm{gr} / \mathrm{cc}$ thus this parameter fulfills the SNI standard. Similarly, the $10 \%$, $20 \%$ and $30 \%$ of the long residue addition respectively into the Siwalan fruit skin charcoal briquette generates porosity bigger than $0,7 \mathrm{gr} / \mathrm{cc}$ and again this parameter is inline with the SNI standard requirement.

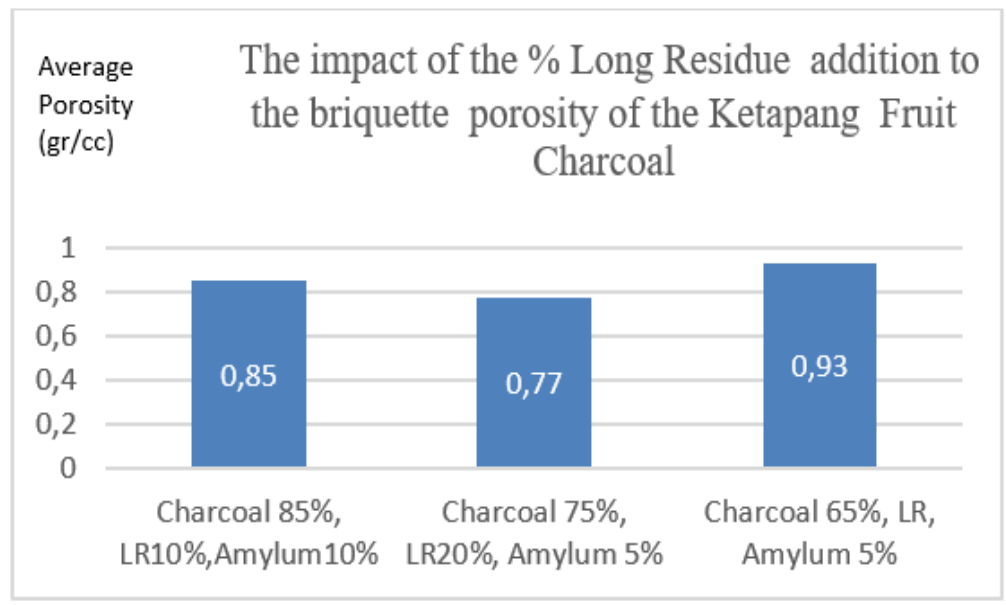

Figure 2 The impact of the $\%$ of long residue addition to the briquette porosity of the Ketapang fruit charcoal

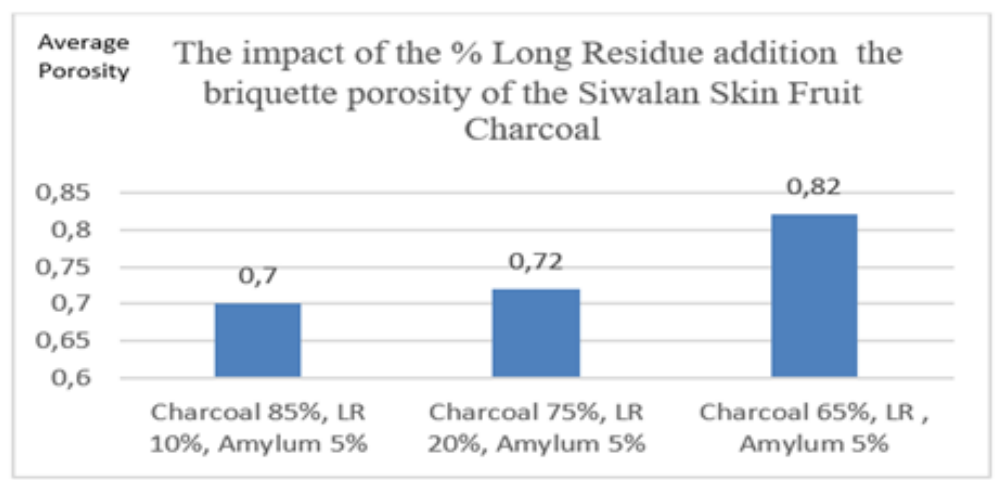

Figure 3 The impact of the $\%$ of long residue addition to the briquette porosity of the Siwalan fruit skin charcoal 


\subsection{The Impact of the \% of Long Residue Addition to the Briquette Proximate Analysis of the Ketapang Fruit Charcoal}

Figure 4 shows the proximate analysis of the Ketapang fruit charcoal briquette. Only briquette moisture content fulfills the SNI standard (ie $8 \%$ adb max). The FC, ash and, VM contents of the briquettes do not fulfill the SNI standard requirements $(60 \%, 8 \%, 15$ $\%$ adb max respectively) even though, they were already added with Long residue up to $30 \%$. Meanwhile figure 5 shows that all briquette calorific values meet the SNI standard requirements $(5000 \mathrm{cal} / \mathrm{gram} \mathrm{adb})$. This is because the Ketapang charcoal itself already poses a calorific value more than $6000 \mathrm{cal} / \mathrm{gram}$. The $10 \%$ upto $30 \%$ of the long residue addition into the briquette mixture increases the calorific value of the briquettes from $2 \%$ up to $6 \%$ (see Table 1 and Fig 5 ).

\subsection{The Impact of the Percentage of the Long Residue Addition to the Briquette Proximate Analysis of the Siwalan Fruit Skin Charcoal}

Figure 6 shows the proximate analysis of the Siwalan fruit skin charcoal briquette. Only moisture content within briquettes fulfills the SNI standard. The FC, ash and, VM contents of the briquettes do not fulfill the SNI requirements even though they were already added with $30 \%$ of Long residue. Figure 7 shows that all briquette calorific values meet the SNI standard. Adding 10\% up to $30 \%$ of long residue increases the briquette calorific value from $2 \%$ up to $11 \%$ (see Table 1 and Fig 7). The briquette compressive strength both for Ketapang fruit and Siwalan fruit skin charcoals does not fulfill the $\mathrm{P} 3 \mathrm{HH}$ standard as a manual molding machine was used. When the briquette samples was tested for their compressive strength they did not give a good performance as the $\mathrm{P} 3 \mathrm{HH}$ requirement. When the use of briquettes are only for a local this last parameter can be ignored.

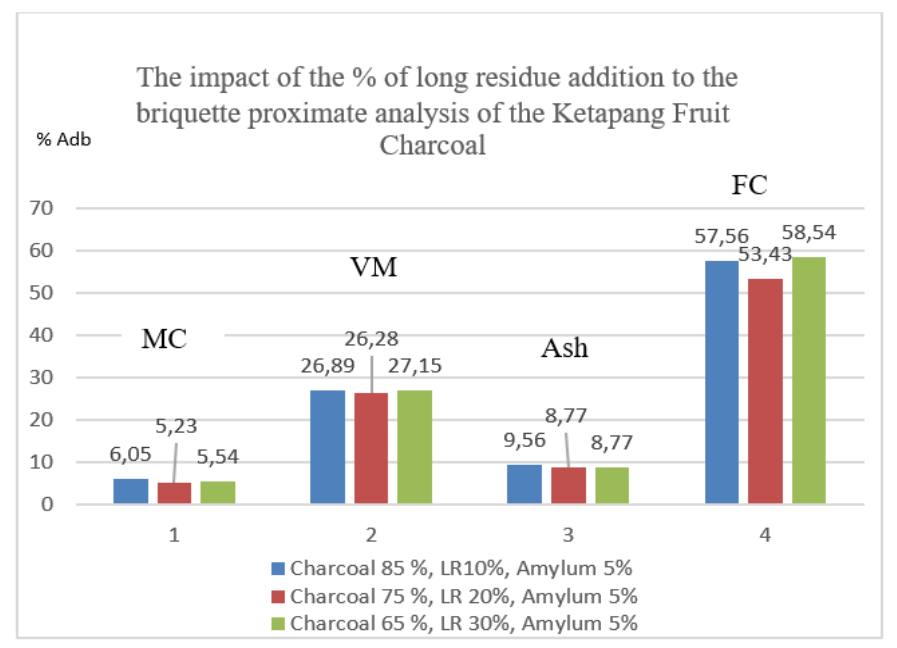

Figure 4 The impact of the $\%$ of Long residue addition to the briquette proximate analysis of the Ketapang fruit charcoal

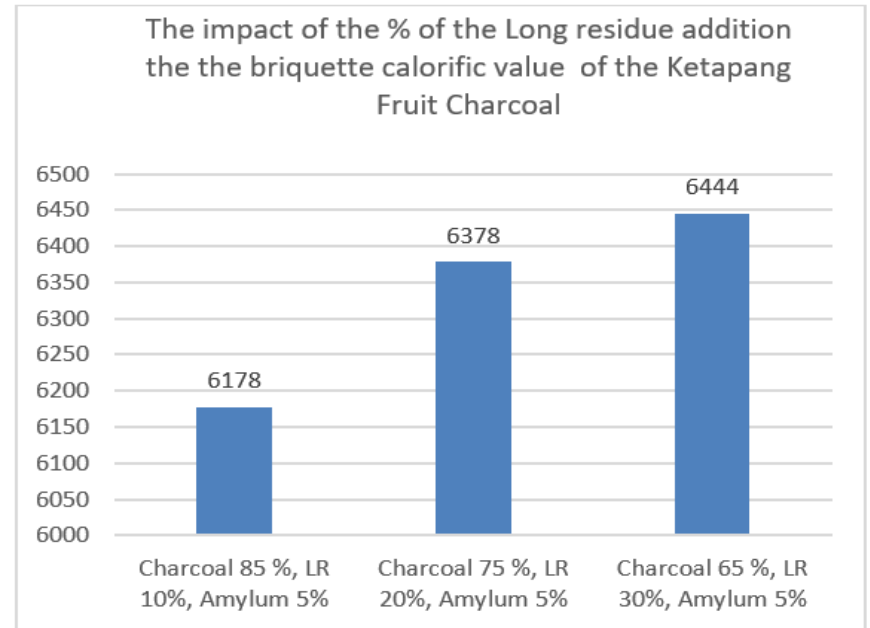

Figure 5 The impact of the \% of Long residue addition to the briquette calorific value of the Ketapang fruit charcoal (CV in $\mathrm{cal} / \mathrm{gr} \mathrm{adb})$ 


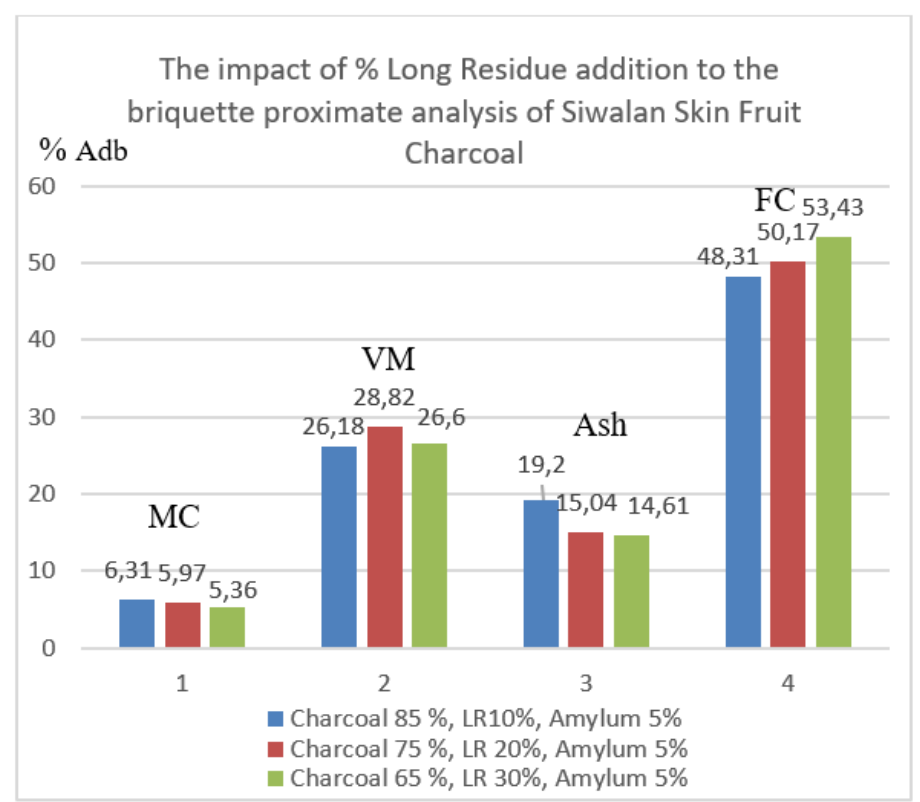

Figure 6 The impact of the \% of Long residue addition to the briquette proximate analysis of Siwalan fruit skin charcoal

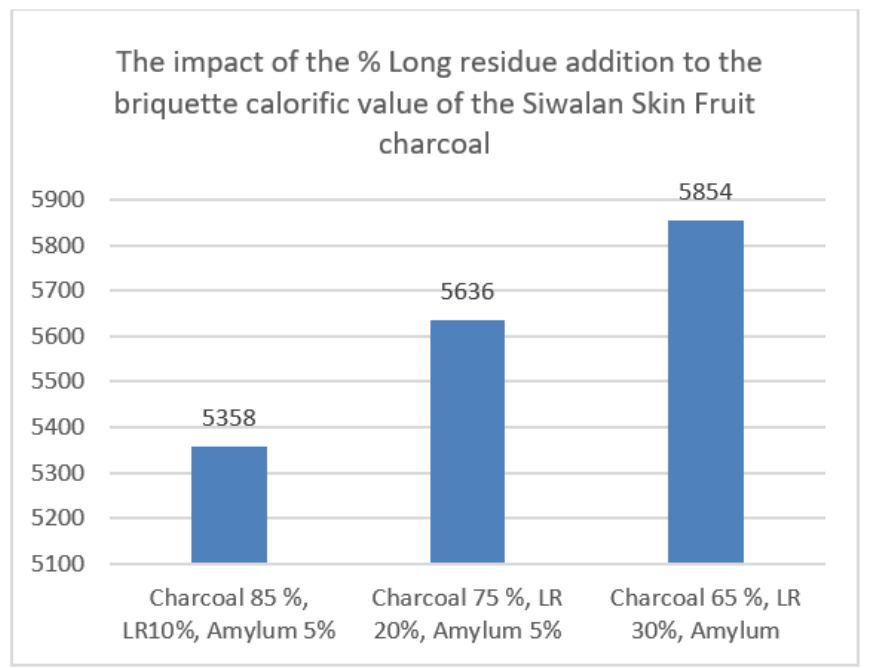

Figure 7 The impact of the \% Long residue addition to the briquette calorific value of the Siwalan fruit skin charcoal

\section{CONCLUSION}

The long residue addition of $10 \%, 20 \%$ and, $30 \%$ weight respectively into the briquette of Ketapang fruit and Siwalan fruit skin could produce the briquettes with a better porosity, moisture content and calorific value and they fulfill the national standard requirements. Nevertheless the FC, ash and VM contents in the briquettes of both Ketapang fruit and Siwalan fruit skin charcoal do not meet the national standard requirements even though the $30 \%$ of long resiudue has been added to the briquette. These three last parameters may relate to the raw materials used and the performance of a charcoal furnace used. The compressive strength of the briquettes also does not fulfill the requirement as a manual molding machine was used for briquette process. If the briquettes are only used to substitute the local energy supply for local villagers then, the briquettes are still appropriate as they may not be transported. Further research needs to be conducted to explore the used of Long residue addition in briquette production from other types of biomass which is plenty in our surroundings.

\section{ACKNOWLEDGMENTS}

Thank you to Prof Perry Burhan, the Director of Politeknik Energi dan Mineral AKAMIGAS and Dr. 
Puspa Ratu, the Head of The PEM AKAMIGAS Research Centre who provided the research funding. Thank you to Mr. Arif Nurochman, the Head of The Oil and Gas Process Engineering Department and Dr. Tun Sriyana, the Head of the Operating Technology Laboratory who permitted to use the laboratory facilities.

\section{REFERENCES}

[1] T. T. Idzni Qistina, Dede Sukandar, "Kajian Kualitas Briket Biomassa dari Sekam Padi dan Tempurung Kelapa,” J. Kim. Val., vol. 2, no. 2, pp. 136-142, 2016.

[2] M. A. Rosdiana Moeksin, Nabila Zarwan, "Pembuatan Biobriket Dari Campuran Tempurung Kelapa Dan Cangkang biji Karet," J. Tek. Kim., vol. 22, no. 3, pp. 43-52, 2016.

[3] E. Elfiano, P. Subekti, and A. Sadil, "Analisa Proksimat Dan Nilai Kalor Pada Briket Bioarang Limbah Ampas Tebu Dan Arang Kayu,” J. Aptek, vol. 6, no. 1, pp. 57-64, 2014.

[4] R. Nurainy, S. Sumiyati, and E. Sutrisno, "Pemanfaatan Ampas Bioetanol Dari Kulit Pisang (Musa Sapientum) Sebagai Briket," J. Tek. Lingkungan; Vol 2, No 2 J. Tek. Lingkung., [Online]. Available: https://ejournal3.undip.ac.id/index.php/tlingkungan /article/view/2730.

[5] T. WIJAYANTI, "Pembuatan Biobriket dari Campuran Limbah Kacang Tanah dan Limbah Kacang Mete Menggunakan Perekat Tetes Tebu," J. Pendidik. Tek. Mesin, vol. 01, no. 01, 2012.

[6] H. S. Nurkholis Hamidi, ING Wardana, "Pengaruh Penambahan Tongkol Jagung Terhadap Performa Pembakaran Bahan Bakar Briket Blotong (Filter Cake)," J. Rekayasa Mesin, vol. 2, no. 2, pp. 92-97, 2011.

[7] S. M. S. Lilik Dwi Sulistyorini, Musthofa Lutfi, "Pemanfaatan Kulit Siwalan (Borassus Flabellifer) Sebagai Biochar Dengan Pengaruh Konsentrasi Dan Lama Perendaman Hcl Pada Proses Aktivasi," J. Bioproses Komod. Trop., vol. 3, no. 2, pp. 74-80, 2015.

[8] H. T. B. M. Yuniarti, Suryo Purwono, Tinjauan Kinetika Reaksi Pirolisis Cangkang Biji Ketapang Untuk Menghasilkan Bahan Bakar Briket Arang. 2016.
[9] M. Syamsiro, "Peningkatan Kualitas Bahan Bakar Padat Biomassa Dengan Proses Densifikasi Dan Torrefaksi," J. Mek. dan Sist. Termal, vol. 1, no. 1, pp. 7-13, 2016.

[10] J. N. A. Rasyidi Fachry, Tuti Indah Sari, Arco Yudha Dipura, "Mencari Suhu Optimal Proses Karbonisasi Dan Pengaruh Campuran Batubara Terhadap Kualitas Briket Eceng Gondok," J. Tek. Kim., vol. 2, no. 17, pp. 55-67, 2010.

[11] H. R. R. Siti Miskah, Lucya Suhirman, "Pembuatan Biobriket Dari Campuran Arang Kulit Kacang Tanah Dan Arang Ampas Tebu Dengan Aditif Kmno4," J. Tek. Kim., vol. 20, no. 3, pp. 12-21, 2014.

[12] I. W. S. Tri Kusuma Wardani, "Campuran Arang Limbah Ampas Tebu (Bagasse) Dan Arang Tempurung Kelapa Dengan Perekat Tetes Tebu,” J. Tek. Mesin, vol. 3, no. 1, pp. 126-134, 2014.

[13] A. E. P. Eko Yudi Aristiyanto and U. Jurusan Teknik Mesin, Fakultas Teknik, "Pembuatan Biobriket Dari Campuran Limbah Kulit Pisang Dan Serbuk Gergaji Menggunakan Perekat Tetes Tebu," J. Tek. Mesin, vol. 3, no. 1, pp. 89-95, 2014.

[14] D. Patabang, "Karakteristik Termal Briket Arang Sekam Padi Dengan Variasi Bahan Perekat," J. Mek., vol. 3, no. 2, pp. 286-292, 2012.

[15] R. Setiowati and M.Tirono, "Pengaruh Variasi Tekanan Pengepresan Dan Komposisi Bahan Terhadap Sifat Fisis Briket Arang," J. Neutrino, vol. 7, no. 1, pp. 23-31, 2014.

[16] R. Rindayatno and D. Lewar, "Kualitas Briket Arang Berdasarkan Komposisi Campuran Arang Kayu Ulin (Eusideroxylon zwageri Teijsm \& Binn) Dan Kayu Sengon (Paraserianthes falcataria)," Ulin J. Hutan Trop., vol. 1, 2017, doi: 10.32522/ujht.v1i1.792.

[17] A. Renny Eka Putri, "Studi Mutu Briket Arang Dengan Bahan Baku Limbah Biomassa,” J. Teknol. Pertan. Andalas, vol. 21, no. 2, pp. 143-151, 2017.

[18] W. R. Hatiningrum and and A. D. R. , Suparno, A Huzein, R D Syahputra, "The effect of the carbonization period to the yield of biomass charcoals of secang, roda, ketapang and siwalan fruits using the small scale PEM A - HRV furnace," J. Phys. Conf. Ser., vol. 1517, no. 1, pp. 1-6, 2020. 